University of Nebraska - Lincoln

DigitalCommons@University of Nebraska - Lincoln

Biological Systems Engineering: Papers and

Publications

Biological Systems Engineering

2009

\title{
Sorghum distillers dried grain lipid extract increases cholesterol excretion and decreases plasma and liver cholesterol concentration in hamsters
}

\author{
Jia Tse Hoi \\ University of Nebraska-Lincoln \\ Curtis L. Weller \\ University of Nebraska-Lincoln, cweller1@unl.edu \\ Vicki Schlegel \\ University of Nebraska-Lincoln, vschlegel3@unl.edu \\ Susan L. Cuppett \\ University of Nebraska-Lincoln, scuppett1@unl.edu \\ Ji-Young Lee \\ University of Nebraska-Lincoln, ji-young.lee@uconn.edu
}

See next page for additional authors

Follow this and additional works at: https://digitalcommons.unl.edu/biosysengfacpub

Part of the Biological Engineering Commons

Hoi, Jia Tse; Weller, Curtis L.; Schlegel, Vicki; Cuppett, Susan L.; Lee, Ji-Young; and Carr, Timothy P., "Sorghum distillers dried grain lipid extract increases cholesterol excretion and decreases plasma and liver cholesterol concentration in hamsters" (2009). Biological Systems Engineering: Papers and Publications. 188.

https://digitalcommons.unl.edu/biosysengfacpub/188

This Article is brought to you for free and open access by the Biological Systems Engineering at DigitalCommons@University of Nebraska - Lincoln. It has been accepted for inclusion in Biological Systems Engineering: Papers and Publications by an authorized administrator of DigitalCommons@University of Nebraska Lincoln. 


\section{Authors}

Jia Tse Hoi, Curtis L. Weller, Vicki Schlegel, Susan L. Cuppett, Ji-Young Lee, and Timothy P. Carr 


\title{
Sorghum distillers dried grain lipid extract increases cholesterol excretion and decreases plasma and liver cholesterol concentration in hamsters
}

\author{
Jia Tse Hoi, ${ }^{1}$ Curtis L. Weller, ${ }^{2,3}$ Vicki L. Schlegel, ${ }^{3}$ \\ Susan L. Cuppett, ${ }^{3}$ Ji-Young Lee, ${ }^{1}$ and Timothy P. Carr ${ }^{1}$ \\ 1. Department of Nutrition and Health Sciences, \\ University of Nebraska-Lincoln, Lincoln, NE 68583, USA \\ 2. Department of Biological Systems Engineering, \\ University of Nebraska-Lincoln, Lincoln, NE 68583, USA \\ 3. Department of Food Science and Technology, \\ University of Nebraska-Lincoln, Lincoln, NE 68583, USA \\ Corresponding author - T. P. Carr, Nutrition and Health Sciences, 316 Leverton Hall, University of \\ Nebraska-Lincoln, Lincoln, NE 68583, USA; tel 402 472-7940, fax 402 472-1587, email tcarr2@unl.edu
}

\begin{abstract}
Grain sorghum is a rich source of phytochemicals. In this study, male hamsters were fed AIN-93M diets supplemented with a hexane-extractable lipid fraction from sorghum distillers dried grains with solubles (DDGS). Diets contained $0.0 \%, 0.5 \%$, $1.0 \%$, and $5.0 \%(\mathrm{w} / \mathrm{w})$ DDGS lipid extract. After $4 \mathrm{wk}$, the 5.0\% DDGS lipids group had significantly lower plasma non-HDL cholesterol and liver esterified cholesterol concentration. Fecal neutral sterol (i.e., cholesterol) excretion was significantly higher in the 5.0\% DDGS lipids group compared to the other treatments (66\% higher compared to controls). Bile acid excretion was not affected by DDGS lipid intake. Fecal cholesterol excretion was negatively correlated with liver cholesterol concentration $(r=-0.97, P=0.026)$, and liver cholesterol concentration was directly correlated with plasma total cholesterol concentration $(r=0.96, P=0.041)$. Thus, lipid extract of sorghum DDGS exhibited cholesterol-lowering properties due, at least in part, to increased cholesterol excretion from the body and could provide health benefits when incorporated into human diets.
\end{abstract}

Keywords: cholesterol, sorghum, sterols, lipid extract, hamsters

Abbreviations: DDGS, distillers dried grains with solubles; LDL, low density lipoprotein; HDL, high density lipoprotein; VLDL, very low density lipoprotein; NPC1L1, Niemann-Pick C1 like 1; SRB1, scavenger receptor class B type 1; SREBP2, sterol regulatory element binding protein-2; HMGR, 3-hydroxy-3-methylglutaryl-CoA reductase; LDLR, low density lipoprotein receptor; ABCA1, ATP-binding cassette transporter A1; CYP7A1, cholesterol 7 $\alpha$-hydroxylase; GAPDH, glyceraldehyde-3-phosphate dehydrogenase

\section{Introduction}

Coronary heart disease (CHD) is a leading cause of death for both men and women in the United States. CHD is characterized by the formation of atherosclerosis, the narrowing of the arteries that supply oxygen and blood to the heart (Lloyd-Jones et al., 2009). While CHD is a multifactorial disease, elevated total and low density lipopro- tein (LDL) cholesterol and decreased high density lipoprotein (HDL) cholesterol are perhaps the most important risk factors for CHD (Martin et al., 1986; Pekkanen et al., 1990).

Plasma LDL cholesterol can be lowered with both diet modification and with the use of cholesterol-lowering drugs. Several classes of drugs can lower plasma LDL cholesterol, including statins, bile acid sequestrants, nicotinic acid, fibrates, and cholesterol absorption inhibitors. Statin drugs provide 
effective cholesterol-lowering therapy and are widely prescribed (Stein, 2003), but they are costly and can cause severe side effects such as elevated serum levels of liver enzymes, skeletal muscle abnormalities, cognitive impairment, and even death (Evans and Rees, 2002; Farmer, 2003).

Food-derived alternative cholesterol-lowering agents include dietary fiber, soy protein, and phytosterols (Carr and Jesch, 2006). Phytosterols, as free sterols or esterified to fatty acids, can play an important role in the reduction of plasma cholesterol in humans (Katan et al., 2003), especially for individuals who cannot tolerate statins or other cholesterol-lowering drugs. A recent study in our laboratory indicated that whole kernel grain sorghum lipid extract reduced cholesterol absorption and plasma non-HDL cholesterol concentration in hamsters (Carr et al., 2005), which was attributed to phytosterols (and, possibly, policosanols) present in the whole kernel extract. Grain sorghum is a rich source of many phytochemicals (Awika and Rooney, 2004), yet this abundant cereal crop has been largely overlooked for its health benefits (Dicko et al., 2006). Historical concerns raised most often regarding grain sorghum are its poor digestibility, low protein content and quality, deficiency of Vitamins A and E, and low bioavailability of zinc and iron (FAO, 1995). More current research has emphasized that the antioxidant properties of polyphenolic compounds in many sorghum varieties may outweigh the disadvantages and that household processing techniques can overcome antinutritional properties (Awika and Rooney, 2004; Hotz and Gibson, 2007).

The purpose of this research was to determine whether lipid extracts of sorghum distillers dried grain with solubles (DDGS) had cholesterol-lowering properties similar to extracts of sorghum whole kernels. DDGS is a byproduct of the ethanol industry and is primarily used for animal feed, yet many of the phytochemicals present in whole kernels are retained in the DDGS after starch depletion (Hwang et al., 2004). Male Syrian hamsters were used to document the impact of DDGS lipid extract on plasma and liver cholesterol, sterol and bile acid excretion, and expression of genes involved in sterol metabolism.

\section{Materials and methods}

\subsection{Animal care}

Male $\mathrm{F}_{1} \mathrm{~B}$ Syrian hamsters (Bio Breeders, Watertown, MA) aged $7 \mathrm{wk}$ and weighing $\sim 80 \mathrm{~g}$ were randomly assigned to treatment groups ( $n=8-10 /$ treatment) and housed individually in polycarbonate cages with sawdust bedding. Hamsters were kept in a $25^{\circ} \mathrm{C}$ room with a 12-h light:dark cycle and had free access to food and water throughout the 4-wk feeding period. All experimental procedures were approved by the Institutional Animal Care and Use Committee at the University of Nebraska (protocol \#04-12-059).

\subsection{Diets}

Hamsters were fed a modified AIN-93M diet supplemented with $0.0 \%, 0.5 \%, 1.0 \%$, or $5.0 \%(\mathrm{w} / \mathrm{w})$ lipids extracted from sorghum DDGS (Table 1). The sorghum DDGS
Table 1. Composition of control diet fed to hamsters

\begin{tabular}{lc}
\hline Ingredient & $\mathrm{g} / \mathrm{kg}$ diet \\
\hline Cornstarch $^{\mathrm{a}}$ & 465.2 \\
Dextrinized cornstarch $^{\mathrm{b}}$ & 155.0 \\
Casein & 140.0 \\
Sucrose & 100.0 \\
Palm oil & 30.0 \\
Soybean oil & 10.0 \\
Cel1ulose & 50.0 \\
Cholesterol & 0.5 \\
AIN-93 mineral mix & 35.0 \\
AIN-93 vitamin mix & 10.0 \\
L-Cystine & 1.8 \\
Choline bitartrate & 2.5
\end{tabular}

a. Control diet contained 0\% DDGS lipids. Treatment diets contained $0.5 \%, 1.0 \%$, and $5.0 \%$ DDGS lipids and were added at the expense of cornstarch.

b. Dyetrose (Dyets, Bethlehem, PA).

c. Solka-Floc (International Fibre Corporation, North Tonawanda, NY).

was obtained in 2006 from Energy Partners (now White Energy, Russell, Kansas) that processes mixed commercial grain sorghum hybrids for ethanol. A bench-scale extractor, as constructed by Weller et al. (2006), was used to extract the lipids from the DDGS samples.

\subsection{Plasma and liver lipids}

On day 28, hamsters were euthanized by $\mathrm{CO}_{2}$ asphyxiation. Blood was collected by cardiac puncture using 10$\mathrm{mL}$ syringes containing $10 \mathrm{mg}$ ethylenediaminetetraacetic acid (EDTA) as an anticoagulant. Red blood cells were removed by centrifugation at $1000 \mathrm{~g}$ for $30 \mathrm{~m}$ at $4{ }^{\circ} \mathrm{C}$. Aprotinin $(1 \mathrm{mg} / \mathrm{L})$ and phenylmethylsulphonyl fluoride (80 $\mathrm{mg} / \mathrm{L}$ ) were added to the plasma as preservatives. Plasma total cholesterol concentration was determined enzymatically using a microplate method (Carr et al., 1993). Plasma HDL cholesterol concentration was measured after apolipoprotein B precipitation, and non-HDL cholesterol (VLDL + LDL) was calculated by difference. Previous hamster studies in our laboratory showed that the non-HDL plasma fraction contains $>90 \%$ LDL cholesterol (Carr et al., 2000). Livers were perfused with saline through the portal vein to eliminate residual blood before being excised. Livers were weighed, immediately frozen in liquid nitrogen, and stored at $-80{ }^{\circ} \mathrm{C}$. Aliquots of frozen liver were minced and lipids extracted into chloroform/methanol (2:1, v/v) (Folch et al., 1957). Total cholesterol, free cholesterol, triacylglycerol, and phospholipid were quantified enzymatically (Carr et al., 1993), and liver esterified cholesterol was calculated as the difference between total and free cholesterol.

\subsection{Fecal sterol analysis}

Feces were collected during wk 4 for quantification of cholesterol-derived neutral steroids and bile acids. The following neutral steroids were quantified and represent fecal cholesterol and its metabolites: cholesterol, coprostanol, dihydrocholesterol, epicoprostanol, epicholestanol, copros- 
tanone, and cholestanone. Ground feces $(\sim 100 \mathrm{mg})$ were acidified by adding $0.2 \mathrm{~mL}$ of $0.5 \mathrm{~mol} / \mathrm{L} \mathrm{HCl}$. Lipids were then extracted into chloroform/methanol (2:1, v/v) (Folch et al., 1957) containing $10 \mathrm{mg} / \mathrm{L} 5 \alpha$-cholestane as an internal standard. The lower phase solvent was evaporated and the samples saponified in $2 \mathrm{~mL}$ of $1 \mathrm{~mol} / \mathrm{L}$ methanolic $\mathrm{KOH}$ for $1 \mathrm{~h}$ at $50{ }^{\circ} \mathrm{C}$. After the addition of $2 \mathrm{~mL}$ deionized water, the fecal steroids were extracted into $5 \mathrm{~mL}$ hexane. The hexane was evaporated under nitrogen and the steroids derivatized and analyzed by gas chromatography as previously described (Schneider et al., 2000). Fecal bile acid concentration was quantified enzymatically as previously described (Schneider et al., 2000).

\subsection{Total RNA isolation and quantitative real-time PCR}

Liver samples ( $\sim 0.5 \mathrm{~g})$ were used for total RNA extraction using TRIzol reagent (Invitrogen, Carlsbad, CA) following the manufacturer's protocol. Reverse transcription for cDNA synthesis and quantitative real-time PCR analysis were performed as previously described (Park et al., 2008; Rasmussen et al., 2008). Primers listed in Table 2 for the following genes were designed according to GenBank database using the Primer Express 3.0 software provided by ABI: Niemann-Pick C1 like 1 (NPC1L1), scavenger receptor class $B$ type 1 (SRB1), sterol regulatory element binding protein-2 (SREBP2), 3-hydroxy-3- methylglutaryl-CoA reductase (HMGR), LDL receptor (LDLR), ATP-binding cassette transporter A1 (ABCA1), cholesterol 7 $\alpha$-hydroxylase (CYP7A1), and glyceraldehyde-3-phosphate dehydrogenase (GAPDH).

\subsection{Statistical analysis}

All data are expressed as means \pm SEM. Data were found to be normally distributed; therefore, treatment dif- ferences were determined by one-way ANOVA, followed by Student-Newman-Keuls multiple comparison procedure (GraphPad Prism 5, La Jolla, CA). Pearson correlation was used to compare fecal sterol excretion and liver cholesterol concentration. Mean differences were considered significant at $P<0.05$.

\section{Results}

Hamster body weights were not significantly different among the treatment groups at any point during the $4 \mathrm{wk}$ study. Hamsters continued to grow (average gain $22.7 \pm$ $0.5 \mathrm{~g} / 4 \mathrm{wk}$ ) and appeared healthy throughout the study. In subsequent calculations in which metabolic data are normalized to $100 \mathrm{~g}$ of body weight, we used individual body weights as measured on the final day of the study.

Plasma non-HDL cholesterol concentration was significantly lower in hamsters fed 5.0\% DDGS lipids compared to $0.5 \%$ DDGS lipids and tended to be lower compared to the other groups (Table 3). Plasma HDL cholesterol was also significantly lower in the 5.0\% DDGS lipids group compared to the others, which was expected since hamsters are considered an "HDL mammal" (Trautwein et al., 1993). Plasma triacylglycerol concentration was not significantly affected by the level of DDGS lipids consumed.

Liver weights, normalized to $100 \mathrm{~g}$ body $\mathrm{wt}$, were not significantly different among treatments (Table 4). Liver free cholesterol and esterified cholesterol concentrations were significantly lower in the 5.0\% DDGS lipids group compared to hamsters fed $0.5 \%$ DDGS lipids, whereas liver triacylglycerol was significantly higher in the $1.0 \%$ and $5.0 \%$ DDGS groups (Table 4). Liver phospholipid concentration was not significantly affected by the level of DDGS lipids consumed.

Hepatic gene expression of NPC1L1, SRB1, SREBP2, HMGR, LDLR, and CYP7A1 was not significantly different

Table 2. Real-time PCR primers.

\begin{tabular}{|c|c|c|}
\hline Gene & Forward primer & Reverse primer \\
\hline SRB1 & 5'-AAGCCTGCAGGTCTATGAAGC-3' & 5' -AGAAACCITCATTGGGTGGGTA-3' \\
\hline SREPB2 & 5'-GGCCCTGGAAGTGACTGAGA-3' & 5' -GCATGGCTCTACAGGCATAGAA-3' \\
\hline HMGR & 5'-CGAAGGGTTTGCGGTGAT-3' & 5' -TCTGTAGACGTGCAAATCTGCTAGT-3' \\
\hline LDLR & 5'-AGACACATGCGACAGGAATGAG-3' & 5' -GACCCACITGCTGGCGATA-3' \\
\hline
\end{tabular}

Values are means \pm SEM, $n=8$-10. Means in the same column having different superscripts are significantly different $(P<0.05)$.

Table 3. Plasma lipid concentration of hamsters fed sorghum DDGS extract for 4 weeks.

\begin{tabular}{lccc}
\hline DDGS (\%) & $\begin{array}{c}\text { Non-HDL cholesterol } \\
(\mathrm{mmol} / \mathrm{L})\end{array}$ & $\begin{array}{c}\text { HDL cholesterol } \\
(\mathrm{mmol} / \mathrm{L})\end{array}$ & $\begin{array}{c}\text { Triacylglycerol } \\
(\mathrm{mmol} / \mathrm{L})\end{array}$ \\
\hline 0.0 & $1.544 \pm 0.1^{\mathrm{ab}}$ & $2.347 \pm 0.0^{\mathrm{b}}$ & $2.227 \pm 0.3$ \\
0.5 & $1.746 \pm 0.1^{\mathrm{b}}$ & $2.367 \pm 0.1^{\mathrm{b}}$ & $2.533 \pm 0.2$ \\
1.0 & $1.569 \pm 0.2^{\mathrm{ab}}$ & $2.160 \pm 0.1^{\mathrm{b}}$ & $2.403 \pm 0.2$ \\
5.0 & $1.076 \pm 0.2^{\mathrm{a}}$ & $1.708 \pm 0.2^{\mathrm{a}}$ & $2.499 \pm 0.3$ \\
\hline
\end{tabular}

Values are means \pm SEM, $n=8-10$. Means in the same column having different superscripts are significantly different $(P<0.05)$. 
Table 4. Liver weight and lipid concentration in hamsters fed sorghum DDGS lipid extract for 4 weeks.

\begin{tabular}{|c|c|c|c|c|c|}
\hline DDGS (\%) & $\begin{array}{c}\text { Liver weight } \\
\text { (g } 100 \mathrm{~g}^{-1} \text { body weight) }\end{array}$ & $\begin{array}{l}\text { Free cholesterol } \\
(\mu \mathrm{mol} / \mathrm{g})\end{array}$ & $\begin{array}{l}\text { Esterified cholesterol } \\
(\mu \mathrm{mol} / \mathrm{g})\end{array}$ & $\begin{array}{c}\text { Triacylglycerol } \\
(\mu \mathrm{mol} / \mathrm{g})\end{array}$ & $\begin{array}{l}\text { Phospholipid } \\
(\mu \mathrm{mol} / \mathrm{g})\end{array}$ \\
\hline$\overline{0.0}$ & $3.27 \pm 0.04$ & $5.88 \pm 0.08^{\mathrm{ab}}$ & $24.04 \pm 1.24^{b}$ & $7.06 \pm 0.52^{\mathrm{a}}$ & $22.38 \pm 0.36$ \\
\hline 0.5 & $3.42 \pm 0.08$ & $6.01 \pm 0.16^{\mathrm{b}}$ & $23.65 \pm 1.18^{\mathrm{b}}$ & $10.05 \pm 1.35^{\mathrm{ab}}$ & $22.52 \pm 0.43$ \\
\hline 5.0 & $3.31 \pm 0.05$ & $5.53 \pm 0.12^{\mathrm{a}}$ & $12.95 \pm 1.81^{\mathrm{a}}$ & $14.18 \pm 2.73^{b}$ & $22.35 \pm 0.44$ \\
\hline
\end{tabular}

Values are means \pm SEM, $n=8-10$. Means in the same column having different superscripts are significantly different $(P<0.05)$.

Table 5. Hepatic gene expression in hamsters fed sorghum DDGS lipid extract for 4 weeks.

\begin{tabular}{lccccccc}
\hline DDGS $(\%)$ & NPC1L1 & SRB1 & ABCA1 & SREBP2 & HMGR & LDLR & CYP7A1 \\
\hline 0.0 & $1.08 \pm 0.12$ & $1.09 \pm 0.12$ & $0.85 \pm 0.12^{\mathrm{ab}}$ & $1.24 \pm 0.06$ & $0.83 \pm 0.05$ & $0.91 \pm 0.10$ & $1.23 \pm 0.25$ \\
0.5 & $0.98 \pm 0.11$ & $1.19 \pm 0.06$ & $0.77 \pm 0.05^{\mathrm{a}}$ & $1.39 \pm 0.07$ & $0.87 \pm 0.06$ & $0.91 \pm 0.09$ & $0.97 \pm 0.31$ \\
1.0 & $1.29 \pm 0.35$ & $1.24 \pm 0.19$ & $0.92 \pm 1.10^{\mathrm{ab}}$ & $1.52 \pm 0.15$ & $0.97 \pm 0.19$ & $1.00 \pm 0.18$ & $0.99 \pm 0.30$ \\
5.0 & $1.25 \pm 0.23$ & $0.92 \pm 0.15$ & $1.16 \pm 0.10^{\mathrm{b}}$ & $1.43 \pm 0.12$ & $0.92 \pm 0.11$ & $1.11 \pm 0.10$ & $0.71 \pm 0.20$ \\
\hline
\end{tabular}

Values are means \pm SEM $(n=8-10)$ of relative units normalized to the housekeeping gene, GAPDH. Means in the same column having different superscripts are significantly different $(P<0.05)$.

among treatment groups (Table 5). However, liver ABCA1 expression was significantly higher in hamsters fed 5.0\% DDGS lipids compared to controls and 0.5\% DDGS group. ABCA1 expression in hamsters fed $0.5 \%$ and $1.0 \%$ DDGS lipids were not significantly different compared to controls.

Cholesterol excretion from the body was represented by both fecal bile acid and fecal neutral steroid output, expressed as $\mu \mathrm{mol}$ per day, normalized to $100 \mathrm{~g}$ body wt (Table 6). Fecal total bile acids were not significantly different among groups; however, fecal neutral steroid output increased in parallel with increased intake of DDGS lipids. Fecal neutral steroids accounted for the majority $(>91 \%)$ of total sterol output.

A strong negative correlation $(r=-0.97, P=0.026)$ was observed between fecal cholesterol excretion and liver cholesterol concentration (Figure 1), suggesting a dependency of liver cholesterol concentration on intestinal cholesterol uptake. Consequently, liver cholesterol concentration was strongly correlated with plasma total cholesterol $(r=0.96$, $P=0.041)$.

\section{Discussion}

This hamster study was conducted to determine the influence of sorghum DDGS lipid extract on several aspects of cholesterol metabolism known to influence human health. Previous experiments showed that grain sorghum lipid extracted from whole kernels significantly lower plasma and liver cholesterol. Grain sorghum lipid extract appeared to exert its cholesterol-lowering effect by reducing cholesterol absorption with a concomitant increase in fecal sterol excretion as its primary mechanism of action (Carr et al., 2005). Our current findings indicate similar metabolic responses when hamsters were fed the lipid fraction extracted from sorghum DDGS.

Our assumption was that lipids extracted from either whole kernels or DDGS would consist of similar components, and that increased cholesterol excretion (i.e., decreased cholesterol absorption) was most likely caused by
Table 6. Cholesterol output of hamsters fed sorghum DDGS lipid extract for 4 weeks.

\begin{tabular}{llll}
\hline DDGS $(\%)$ & \multicolumn{1}{c}{ Bile acids } & Neutral steroids & Total \\
\cline { 2 - 3 } & \multicolumn{3}{c}{$\left(\mu \mathrm{mol} \mathrm{day}{ }^{-1} 100 \mathrm{~g}^{-1}\right.$ body wt $)$} \\
\hline 0.0 & $0.160 \pm 0.01$ & $2.495 \pm 0.10^{\mathrm{a}}$ & $2.674 \pm 0.11^{\mathrm{a}}$ \\
0.5 & $0.129 \pm 0.01$ & $2.996 \pm 0.12^{\mathrm{b}}$ & $3.154 \pm 0.13^{\mathrm{b}}$ \\
1.0. & $0.167 \pm 0.03$ & $3.476 \pm 0.18^{\mathrm{c}}$ & $3.643 \pm 0.19^{\mathrm{c}}$ \\
5.0 & $0.223 \pm 0.07$ & $4.140 \pm 0.18^{\mathrm{d}}$ & $4.534 \pm 0.08^{\mathrm{d}}$ \\
\hline
\end{tabular}

Values are means \pm SEM, $n=8-10$. Means in the same column having different superscripts are significantly different $(P<0.05)$.

plant sterols. Several studies in humans and animals have demonstrated the ability of dietary plant sterols to inhibit cholesterol absorption and reduce plasma LDL cholesterol concentration (Law, 2000; Katan et al., 2003; Ostlund, 2004). Plant sterol ester fortified foods for human consumption have been shown to lower LDL cholesterol levels up to 15\% compared to placebo when administrated doses of 1-3 g/day (Katan et al., 2003). Accordingly, the National Cholesterol Education Program (2002) and the American Heart Association (Lichtenstein et al., 2006) now recommend a diet that contains $2 \mathrm{~g} / \mathrm{d}$ of plant sterol esters as an effective cholesterol-lowering therapy. We have shown that plant sterols reduce the amount of intestinal cholesterol uptake into enterocytes by their ability to disrupt the incorporation of cholesterol into micelles, thereby lowering cholesterol absorption (Jesch and Carr, 2006).

Cholesterol-lowering effects occurred with hamsters fed $5.0 \%$ DDGS lipids compared to lower amounts of DDGS lipid intake. With regard to plasma lipid response, hamster non-HDL (or LDL) cholesterol responds similarly to humans when presented with a dietary challenge, making them a useful animal model (Trautwein et al., 1993). Therefore, significant decrease in non-HDL cholesterol in hamsters suggests that sorghum DDGS lipid extracts could provide health benefits to human when incorporated into a normal diet. 


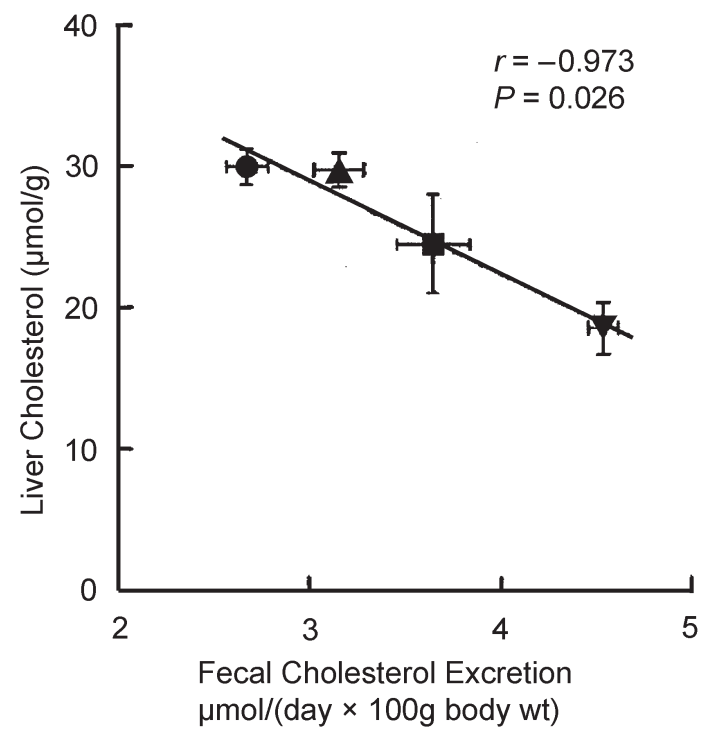

Figure 1. Correlation of fecal cholesterol excretion and liver cholesterol concentration. Each point represents a treatment group of sorghum DDGS lipid extract consumed at $0.0 \%(\boldsymbol{\bullet}), 0.5 \%(\mathbf{\Delta})$, $1.0 \%(\mathbf{\nabla})$, and $5.0 \%(\boldsymbol{\nabla})$ of the diet.

A significant reduction in both free and esterified cholesterol in the liver was seen in the 5.0\% DDGS lipid group. Hamsters fed 5.0\% DDGS lipids exhibited a significant reduction compared to other groups in esterified cholesterol concentration, with a $54 \%$ reduction compared to control. While the reduction of free cholesterol was significant, the magnitude of change among treatment groups was relatively small indicating that free cholesterol in cell membranes is tightly regulated due to its essential role in cell metabolism. The trend of increasing liver triacylglycerol possibly indicates that secretion of VLDL is decreased (Wang et al., 2005), although this was not measured in the current study. Liver phospholipid is an indicator of cell mass and was not affect by dietary treatment.

Fecal neutral sterol excretion was significantly higher in all DDGS lipid groups compared to control, with the 5.0\% DDGS group exhibiting a $66 \%$ increase compared to controls. Fecal bile acids also represent an excretory pathway for cholesterol, although intake of DDGS lipids did not affect bile acid output or gene expression of CYP7A1. These observations therefore indicate that DDGS lipid extract exerts its cholesterol-lowering effect primarily by promoting excretion of intestinal neutral sterols (i.e., cholesterol and its metabolites).

Policosanols were previously reported in humans to lower LDL cholesterol (Varady et al., 2003), possibly by inhibiting cholesterol synthesis (Menendez et al., 1994, 1997). With the assumption that the policosanol content of lipid extract from sorghum DDGS was similar to lipid extract from whole kernels (Carr et al., 2005), and based on total food intake, hamsters in the present study consumed policosanols in the range of $23-230 \mathrm{mg} \mathrm{d}^{-1} \mathrm{~kg}^{-1}$ body wt. Clinical studies suggest that as little as $0.07 \mathrm{mg} \mathrm{d}^{-1} \mathrm{~kg}^{-1}$ can significantly reduce LDL cholesterol concentration (Varady et al., 2003). In the present study, in which 3000-times more policosanol was presumably consumed compared to humans on a body weight basis, no changes were observed in gene expression of HMGR, indicating that policosanol intake in hamsters probably had little impact on regulating plasma cholesterol levels.

Grain sorghum contains phenolic compounds that are beneficial to cardiovascular health due to their ability to reduce inflammation, reduce LDL oxidation, improve endothelial function, and inhibit platelet aggregation (Awika and Rooney, 2004; Arts and Hollman, 2005; Vita, 2005). Additionally, phenolic compounds have demonstrated a modest cholesterol-lowering ability in some studies (Lin et al., 1986; Santos-Buelga and Scalbert, 2000). We did not directly test the effects of sorghum phenolic compounds, although their contribution to cholesterol-lowering should not be underestimated.

\section{Conclusions}

The current evidence suggests that sorghum DDGS lipid extract lowers plasma and liver cholesterol concentrations similarly to grain sorghum lipid extract from whole kernels. Mechanisms by which this occurs are due, at least in part, to increased fecal neutral sterol excretion (i.e., decreased cholesterol absorption). Grain sorghum is a rich source of phytochemicals, including plant sterols; therefore, lipid extracts from whole kernels or DDGS could provide health benefits when incorporated into human diets.

\section{Acknowledgments}

This manuscript is a contribution of the University of Nebraska Agricultural Research Division, supported in part by funds provided through the Hatch Act, USDA. Additional support was provided by the USDA-CSREES National Research Initiative Grant 2004-35503-14824 and USDA-ARS Specific Cooperative Agreement 58-5430-4-362. Mention of a trade name, proprietary products, or company name is for presentation clarity and does not imply endorsement by the authors or the University of Nebraska.

\section{References}

Arts, I. C. W., \& Hollman. P. C. H. (2005). Polyphenols and disease risk in epidemiologic studies. American Journal of Clinical Nutrition 81, 3175-3255.

Awika, J. M., \& Rooney, L. W. (2004). Sorghum phytochemicals and their potential impact on human health. Phytochemistry 65, 1199-1221.

Carr, T. P., Cai, G., Lee, J.-Y., \& Schneider, C. L. (2000). Cholesteryl ester enrichment of plasma low density lipoproteins in hamsters fed cereal-based diets containing cholesterol. Proceedings of the Society of Experimental Biology and Medicine 223, 96-101.

Carr, T. P., Andresen, C. J., \& Rudel, L. L. (1993). Enzymatic determination of triglyceride, free cholesterol, and total cholesterol in tissue lipid extracts. Clinical Biochemistry 26, 39-42.

Carr, T. P., \& Jesch, E. D. (2006). Food components that reduce cholesterol absorption. Advances in Food and Nutrition Research 51, 165-204.

Carr, T. P., Weller, C. L., Schlegel, V. L., Cuppett, S. L., Guderian, D. M., Jr., \& Johnson, K. R. (2005). Grain sorghum lipid extract reduces cholesterol absorption and plasma non-HDL cholesterol concentration in hamsters. Journal of Nutrition 135, 2236-2240. 
Dicko, M. H., Gruppen, H., Traore, A. S., Voragen, A. G. J., \& van Berkel, W. J. H. (2006). Phenolic compounds and related enzymes as determinants of sorghum for food use. Biotechnology and Molecular Biology Reviews 1, 21-38.

Evans, M., \& Rees, A. (2002). Effects of HMG-CoA reductase inhibitors on skeletal muscle: are all statins the same? Drug Safety 25, 649-663.

FAO. (1995). Sorghum and millets in human nutrition. FAO food and nutrition series, no. 27, Food and Agricultural Organization of the United Nations, Rome, Italy.

Farmer, J. A. (2003). Statins and myotoxicity. Current Atherosclerosis Reports 5, 96-100.

Folch, J., Lees, M., \& Sloane-Stanley, G. H. (1957). A simple method for the isolation and purification of total lipids from animal tissues. Journal of Biological Chemistry 224, 497-509.

Hotz, C., \& Gibson, R. S. (2007). Traditional food-processing and preparation practices to enhance the bioavailability of micronutrients in plant-based diets. Journal of Nutrition 137, 1097-1100.

Hwang, K. T., Weller, C. L., Cuppett, S. L., \& Hanna, M. A. (2004). Policosanol contents and composition of grain sorghum kernels and dried distillers grains. Cereal Chemistry 81, 345-349.

Jesch, E. D., \& Carr, T. P. (2006). Sitosterol reduces micellar cholesterol solubility in model bile. Nutrition Research 26, 579-584.

Katan, M. B., Grundy, S. M., Jones, P., Law, M., Miettinen, T., \& Paoletti, R. (2003). Efficacy and safety of plant stanols and sterols in the management of blood cholesterol levels. Mayo Clinic Proceedings 78, 965-978.

Law, M. (2000). Plant sterol and stanol margarines and health. British Medical Journal 320, 861-864.

Lichtenstein, A. H., Appel, L. J., Brands, M., Carnethon, M., Daniels, S., Franch, H. A., Franklin, B., Kris-Etherton, P., Harris, W. S., Howard, B., Karanja, N., Lefevre, M., Rudel, L. L., Sacks, F. M., Van Horn, L., Winston, M., \& Wylie-Rosett, J. (2006). Diet and lifestyle recommendations revision 2006: A scientific statement from the American Heart Association Nutrition Committee. Circulation 114, 82-96.

Lin, B. B., Chen, H. L., \& Huang, P. C. (1986). Effects of instant pauchong tea, catechin, and caffeine on serum-cholesterol and serum low-density-lipoprotein in mice. Nutrition Reports International 34, 821-829.

Lloyd-Jones, D., Adams, R., Carnethon, M., De Simone, G., Ferguson, T. B., Flegal, K., Ford, E., Furie, K., Go, A., Greenlund, K., Haase, N., Hailpern, S., Ho, M., Howard, V., Kissela, B., Kittner, S., Lackland, D., Lisabeth, L., Marelli, A., McDermott, M., Meigs, J., Mozaffarian, D., Nichol, G., O'Donnell, C., Roger, V., Rosamond, W., Sacco, R., Sorlie, P., Stafford, R., Steinberger, J., Thorn, T., Wasserthiel-Smoller, S., Wong, N., Wylie-Rosett, J., \& Hong, Y. (2009). Heart disease and stroke statistics - 2009 update: A report from the American Heart Association Statistics Committee and Stroke Statistics Subcommittee. Circulation 119, e21-e181.

Martin, M. J., Hulley, S. B., Browner, W. S., Kuller, L. H., \& Wentworth, D. (1986). Serum cholesterol, blood pressure, and mortality: Implications from a cohort of 361,662 men. Lancet 2, 933-936.

Menéndez, R., Arruzazabala, L., Más, R., Del Rio, A., Amor, A. M., González, R. M., Carbajal, D., Fraga, V., Molina, V., \& Illnait,
J. (1997). Cholesterol-lowering effect of policosanol on rabbits with hypercholesterolemia induced by a wheat starch-casein diet. British Journal of Nutrition 77, 923-932.

Menéndez, R., Fernández, I., Del Río, A., González, R. M., Fraga, V., Amor, A. M., Jiménez, S., \& Más, R. (1994). Policosanol inhibits cholesterol biosynthesis and enhances LDL processing in cultured human fibroblasts. Biological Research 27, 199-203.

National Institutes of Health. (2002). Third report of the National Cholesterol Education Program (NCEP) expert panel on detection, evaluation, and treatment of high blood cholesterol in adults (Adult Treatment Panel III): Final report. Circulation 106, 3143-3421.

Ostlund, R. E., Jr., (2004). Phytosterols and cholesterol metabolism. Current Opinion in Lipidology 15, 37-41.

Park, Y. K., Rasmussen, H. E., Ehlers, S. J., Blobaum, K. R., Lu, F., Schlegal, V. L., Carr, T. P., \& Lee, J.-Y. (2008). Repression of proinflammatory gene expression by lipid extract of Nostoc commune var. sphaeroides Kützing, a blue-green alga, via inhibition of nuclear factor B in RAW 264.7 macrophages. Nutrition Research 28, 83-91.

Pekkanen, J., Linn, S., Heiss, G., Suchindran, C. M., Leon, A., Rifkind, B. M., \& Tyroler, H. A. (1990). Ten-year mortality from cardiovascular disease in relation to cholesterol level among men with and without preexisting cardiovascular disease. New England Journal of Medicine 322, 1700-1707.

Rasmussen, H. E., Blobaum, K. R., Park, Y.-K., Ehlers, S. J., \& Lee, J. Y. (2008). Lipid extract of Nostoc commune var. sphaeroides Kützing, a blue-green alga, inhibits the activation of sterol regulatory element binding proteins in HepG2 cells. Journal of $\mathrm{Nu}$ trition 138, 476-481.

Santos-Buelga, C., \& Scalbert, A. (2000). Proanthocyanidins and tannin-like compounds: Nature, occurrence, dietary intake and effects on nutrition and health. Journal of the Science of Food and Agriculture 80, 1097-1117.

Schneider, C. L., Cowles, R. L., Stuefer-Powell, C. L., \& Carr, T. P. (2000). Dietary stearic acid reduces cholesterol absorption and increases endogenous cholesterol excretion in hamsters fed cereal-based diets. Journal of Nutrition 130, 1232-1238.

Stein, E. A. (2003). The power of statins: Aggressive lipid lowering. Clinical Cardiology 26 (Suppl. 3), III-25-III-31.

Trautwein, E. A., Liang, J., \& Hayes, K. C. (1993). Plasma lipoproteins, biliary lipids and bile acid profile differ in various strains of Syrian hamsters Mesocricetus auratus. Comparative Biochemistry and Physiology 104A, 829-835.

Varady, K. A., Wang, Y., \& Jones, P. J. H. (2003). Role of policosanols in the prevention and treatment of cardiovascular disease. Nutrition Reviews 61, 376-383.

Vita, J. A. (2005). Polyphenols and cardiovascular disease: Effects on endothelial and platelet function. American Journal of Clinical Nutrition 81, 292S-297S.

Wang, Y., Castoreno, A. B., Stockinger, W., \& Nohturfft, A. (2005). Modulation of endosomal cholesteryl ester metabolism by membrane cholesterol. Journal of Biological Chemistry 280, 11876-11886.

Weller, C. L., Hwang, K. T., \& Schmidt, B. J. (2006). Yield comparisons of different methods of waxy fraction extraction from grain sorghum. Food Science and Biotechnology 15, 786-791. 